\title{
Penggunaan Simple Additive Weighting Dalam Pengembangan Sistem Penunjang Keputusan Penentuan Bonus Karyawan
}

\author{
Meta Amalya Dewi \\ Program Studi Sistem Informasi, School of Engineering Tanri Abeng University Jakarta \\ meta.amalya@tau.ac.id \\ Diterima 30 April 2018 \\ Disetujui 8 Juni 2018
}

\begin{abstract}
Employees are the important aspect to determine company progress. PT. Adiperkasa Anugrah Pratama is a company which engaged in manufacturing by giving bonuses to employees as appreciation action, in determining the employees bonuses they have no precise calculation and potential subjectivity to describe employees dissatisfaction. This research is conducted by using simple additive weighting (SAW) method. This method can find the best alternative to determine the amount of employees bonus by finding job period, job position, departmental function and performance value. This method can determine the solution and the optimal alternative. The application designed by Unified Modeing Language (UML) that implemented in PHP programming language with sublime text 3 and MySQL database type. The result of this study is a supportive system that can assist the management in determining the bonus amount of the employees.
\end{abstract}

Index Terms - employee, position, bonuses, performance.

\section{PENDAHULUAN}

Pemberian bonus merupakan salah satu cara yang telah dilakukan banyak perusahaan untuk memberikan semangat dan motivasi kepada karyawannya [1]. Demikian halnya PT Adiperkasa Anugrah Pratama sebagai perusahaan berkembang yang bergerak di bidang manufaktur dalam menghasilkan produk sparepart kendaraan bermotor merek Honda secara rutin memberikan bonus tahunan sebagai imbalan dan apresiasi kepada karyawannya. Namun dalam penentuan besaran bonus belum memiliki standar perhitungan baku, sehingga besaran bonus yang diterima karyawan kerap menimbulkan ketidakpuasan karena dianggap faktor penentunya adalah like and dislike, kedekatan dengan atasan dan penilaian subyektifitas yang tinggi. Hal ini berpotensi menjadi demotivasi atau penurunan motivasi dan semangat kerja yang akan berdampak pada menurunnya tingkat produktifitas. Sementara dari sisi lain, kinerja Manajer Personalia ditentukan dengan ketepatan waktu penyerahan bonus tahunan kepada karyawan yang faktanya masih sering mengalami keterlambatan karena proses perhitungan yang masih dilakukan secara manual.
Pesatnya perkembangan teknologi yang hadir saat ini mendorong terjadinya perubahan perilaku bisnis [2]. Perusahaan dapat memanfaatkan perkembangan teknologi tersebut untuk menyelesaikan permasalahan perhitungan besaran bonus tahunan karyawan dengan mengembangkan sistem penunjang keputusan menggunakan metode simple additive weighting (SAW) yang sering juga dikenal dengan istilah metode penjumlahan terbobot dengan mencari penjumlahan terbobot dari rating kinerja pada setiap alternatif pada semua atribut [3].

Beberapa penelitian terdahulu yang berhubungan dengan sistem pendukung keputusan menggunakan metode simple additive weighting diantaranya adalah yang berjudul "Sistem Pendukung Keputusan Penentuan Bonus Dengan Metode Simple Additive Weighting (Studi Kasus : PTPN III Sei Karang) dengan menggunakan kriteria keuntungan, golongan, jabatan, gaji dan pajak [4] dan penelitian yang dilakukan oleh Zulkifli dan Sariffudin dengan judul "Decision Support System Pemberian Bonus Karyawan Menggunakan Metode Simple Additive Weighting (Study Kasus : STMIK Pringsewu) dengan menggunakan kriteria masa kerja, kedisiplinan, tanggung jawab dan hasil kerja [5]

Penelitian ini akan membahas bagaimana membangun sistem penunjang keputusan, dengan menyediakan informasi, membimbing, memberikan prediksi serta mengarahkan kepada pengguna informasi agar dapat melakukan pengambilan keputusan yang lebih baik [6] dengan menggunakan 4 kriteria penilaian kinerja karyawan PT Adiperkasa Anugrah Pratama, yaitu masa kerja, jabatan, fungsi kerja, dan hasil kerja.

Langkah Penyelesaian metode SAW [7] adalah sebagai berikut :

1. Menentukan kriteria-kriteria yang akan dijadikan acuan dalam pengambilan keputusan, yaitu $\mathrm{Ci}$. 
2. Menentukan rating kecocokan setiap alternatif pada setiap kriteria.

3. Membuat matriks keputusan berdasarkan kriteria (Ci), kemudian melakukan normalisasi matriks berdasarkan persamaan yang disesuaikan dengan jenis atribut (atribut keuntungan ataupun atribut biaya) sehingga diperoleh matriks ternormalisasi $\mathrm{R}$.

4. Hasil akhir diperoleh dari proses perankingan yaitu penjumlahan dari perkalian matriks ternormalisasi $\mathrm{R}$ dengan vector bobot sehingga diperoleh nilai terbesar yang dipilih sebagai alternatif terbaik (Ai) sebagai solusi.

Formula untuk melakukan normalisasi tersebut adalah:

$r_{i j}=\left\{\begin{array}{l}\frac{X_{i j}}{\operatorname{Max} X_{i j}} \text { Jika } j \text { adalah atribut keuntungan } \\ \quad \text { (benefit) } \\ \frac{\operatorname{Min} X_{i j}}{X_{i j}} \text { Jika } j \text { adalah atribut biaya (cost) }\end{array}\right.$

Dimana rij adalah rating kinerja ternormalisasi Max Xij adalah nilai maksimum dari setiap kriteria Min Xij adalah nilai minimum dari setiap kriteria Xij adalah baris dan kolom dari matriks

Dengan rij adalah rating kinerja ternormalisasi dari alternatif $\mathrm{Ai}$ pada atribut $\mathrm{Cj} ; \mathrm{i}=1,2, \ldots \mathrm{m}$ dan $\mathrm{j}$ $=1,2, \ldots, \mathrm{n}$.

Nilai preferensi untuk setiap alternatif (Vi) diberikan sebagai :

$$
V_{i}=\sum_{j=1}^{n} W_{j} r_{i j}
$$

DimanaVi adalah Nilai akhir dari alternatif $\mathrm{Wj}$ adalah Bobot yang telah ditentukan rij adalah Normalisasi matriks

NilaiVi yang lebih besar mengindikasikan bahwa alternatif Ai merupakan alternatif terbaik.

\section{METODE PENELITIAN}

Pengembangan sistem penunjang keputusan penentuan bonus karyawan dengan menggunakan SAW ini dilakukan melalui tahapan sebagai berikut :

a. Analisa Masalah

Analisa masalah dilakukan untuk mendapatkan gambaran lengkap mengenai permasalahan penentuan perhitungan besaran bonus tahunan karyawan menggunakan kriteria sesai kebutuhan perusahaan.

b. Identifikasi Kebutuhan

Identifikasi kebutuhan dilakukan untuk mengetahui kebutuhan user terhadap sistem pendukung keputusan yang akan dibangun dalam penentuan besaran bonus tahunan karyawan.

c. Desain Sistem
Pada tahap ini sistem didesain menggunakan tools UML, yaitu sebuah bahasa pemodelan untuk perangkat lunak yang berparadigma 'berorientasi objek', sementara pemodelan digunakan untuk penyederhanaan permasalahan kompleks sedemikian rupa sehingga lebih mudah dipahami [8], pemodelan ditulis dengan menggunakan usecase diagram dan class diagram.

d. Implementasi

Pada tahap ini dilakukan pembangunan aplikasi agar User dapat melakukan proses sesuai dengan disain yang telah dibuat dan menampilkan informasi-informasi yang dibutuhkan dengan menggunakan bahasa pemrograman PHP dengan sublime text 3 .

e. Evaluasi

Pada tahap evaluasi ini, user mencoba aplikasi untuk mengetahui apakah aplikasi sudah berjalan dengan baik dan bisa memberikan kepuasan pada user atau tidak. User melakukan analisis kelayakan aplikasi dengan menggunakan PIECES framework yang menilai sistem dari aspek performance, information, economic, control/ security, efficiency, dan services dengan parameter penilaian throughout dan respond time untuk performance; accurate, relevant dan on time untuk information, cost untuk economic, system control untuk control/security, sumberdaya biaya dan tenaga untuk effisiency dan proses layanan untuk services [9].

Alur dari pelaksanaan penelitian ini dapat dilihat pada gambar berikut :

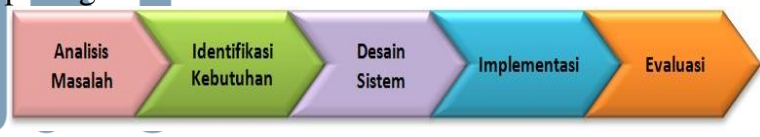

Gambar 1. Alur Penelitian

\section{HASIL DAN PEMBAHASAN}

\section{A. Analisa Masalah}

Dalam proses penggunaan metode SAW memerlukan kriteria-kriteria yang akan dijadikan sebagai bahan perhitungan untuk penentuan besaran bonus karyawan di PT. Adiperkasa Anugrah Pratama dengan berdasarkan pada data penilaian kinerja karyawan dalam satu tahun. Berdasarkan data diperoleh bahwa perusahaan memberikan bobot nilai untuk setiap kriteria berdasarkan tingkat kepentingannya adalah sebagai berikut :

Tabel 1. Bobot Nilai

\begin{tabular}{|l|c|}
\hline Bobot & Nilai \\
\hline Sangat baik & 1 \\
\hline Baik & 0,75 \\
\hline Cukup & 0,50 \\
\hline Kurang & 0,25 \\
\hline
\end{tabular}




\begin{tabular}{|l|c|}
\hline Sangat kurang & 0 \\
\hline
\end{tabular}

\section{B. Identifikasi Kebutuhan}

Untuk menyelesaikan masalah dengan metode simple additive weighting, dibutuhkan urutan kerja sebagai berikut :

Menentukan kriteria-kriteria yang akan dijadikan acuan dalam pengambilan keputusan, yaitu $\mathrm{C}_{1}$. Berdasarkan wawancara yang telah penulis lakukan kepada Manajer Personalia dalam menentukan penilaian kinerja karyawan berdasarkan key performance indicator, maka kriteria yang dipilih dalam menentukan besaran bonus karyawan adalah sebagai berikut :

Tabel 2 Nilai prioritas setiap kriteria

\begin{tabular}{|l|l|c|}
\hline Kriteria & Keterangan & Nilai \\
\hline C1 & Masa kerja & $20 \%$ \\
\hline C2 & Jabatan & $20 \%$ \\
\hline C3 & Fungsi departemen & $30 \%$ \\
\hline C4 & Kinerja & $30 \%$ \\
\hline
\end{tabular}

Berdasarkan tabel di atas, berikutnya adalah bobot nilai dari setiap kriteria yang ditentukan :

a. Kriteria masa kerja

Tabel 3 Nilai bobot kriteria masa kerja (C1)

\begin{tabular}{|l|l|l|}
\hline Masa kerja & Bobot & Nilai \\
\hline 1 tahun masa kerja & Kurang & 0,25 \\
\hline 2 tahun masa kerja & Cukup & 0,50 \\
\hline 5 tahun masa kerja & Baik & 0,75 \\
\hline$>5$ tahun masa kerja & Sangat baik & 1 \\
\hline
\end{tabular}

b. Kriteria jabatan

Tabel 4 Nilai bobot jabatan $(\mathrm{C} 2)$

\begin{tabular}{|l|l|l|}
\hline Jabatan & Bobot & Nilai \\
\hline Kepala Regu & Kurang & 0,25 \\
\hline Kepala Bagian & Cukup & 0,50 \\
\hline Asmen dan Manager & Sangat baik & 1 \\
\hline
\end{tabular}

c. Kriteria fungsi departemen

Tabel 5 Nilai bobot fungsi departemen (C3)

\begin{tabular}{|l|l|l|}
\hline Fungsi departemen & Bobot & Nilai \\
\hline Non produksi & Cukup & 0,50 \\
\hline Support & Baik & 0,75 \\
\hline Produksi & Sangat baik & 1 \\
\hline
\end{tabular}

d. Kriteria kinerja

Tabel 6 Nilai bobot kinerja (C4)

\begin{tabular}{|l|l|l|}
\hline Kinerja & Bobot & Nilai \\
\hline Sangat memuaskan & Sangat baik & 1 \\
\hline Cukup memuaskan & Baik & 0,75 \\
\hline Kurang memuaskan & Kurang & 0,25 \\
\hline
\end{tabular}

1. Menentukan rating kecocokan setiap alternatif pada setiap kriteria.

Berikut di bawah ini merupakan rating kecocokan dari setiap alternatif berdasarkan kriterinya masing-masing.

Tabel 7 Rating kecocokan dari setiap alternatif pada setiap kriteria

\begin{tabular}{|c|l|c|c|c|c|}
\hline N & Alternatif & \multicolumn{4}{|c|}{ Kriteria } \\
\cline { 3 - 6 } o & $\begin{array}{c}\mathrm{C} 1 \\
20 \%\end{array}$ & $\begin{array}{c}\mathrm{C} 2 \\
20 \%\end{array}$ & $\begin{array}{c}\mathrm{C} 3 \\
30 \%\end{array}$ & $\begin{array}{c}\mathrm{C} 4 \\
30 \%\end{array}$ \\
\hline 1 & $\begin{array}{l}\text { A1 (2 kali } \\
\text { Gaji pokok) }\end{array}$ & 1 & 1 & 1 & 1 \\
\hline 2 & $\begin{array}{l}\text { A2 (1 1/2 kali } \\
\text { Gaji pokok) }\end{array}$ & 0,75 & 1 & 0,75 & 1 \\
\hline 3 & $\begin{array}{l}\text { A3 (1 kali } \\
\text { Gaji pokok) }\end{array}$ & 0,50 & 0,75 & 0,25 & 0,75 \\
\hline
\end{tabular}

2. Membuat matriks keputusan berdasarkan kriteria (Ci), kemudian melakukan normalisasi matriks berdasarkan persamaan yang disesuaikan dengan jenis atribut (atribut keuntungan ataupun atribut biaya) sehingga diperoleh matriks ternormalisasi R. Matriks keputusan dibentuk dari tabel kecocokan sebagai berikut di bawah ini :

$$
X=\left\{\begin{array}{cccc}
1 & 1 & 1 & 1 \\
0,75 & 1 & 0,75 & 1 \\
0,50 & 0,75 & 0,25 & 0,75
\end{array}\right\}
$$

Normalisasi matriks menggunakan persamaan 1: Alternatif A1 (2 kali gaji pokok) :

$$
\mathrm{r}_{1,1}=\frac{1}{\operatorname{Max}(1 ; 0,75 ; 0,5)}=\frac{1}{1}=1
$$

$$
\begin{gathered}
\mathrm{r}_{1,2}=\frac{1}{\operatorname{Max}(1 ; 1 ; 0,75)}=\frac{1}{1}=1 \\
\mathrm{r}_{1,3}=\frac{1}{\operatorname{Max}(1 ; 0,75 ; 0,25)}=\frac{1}{1}=1
\end{gathered}
$$$$
\mathrm{r}_{1,4}=\frac{1}{\operatorname{Max}(1 ; 1 ; 0,75)}=\frac{1}{1}=1
$$

Alternatif A2 (1 $1 \frac{1}{2}$ kali gaji pokok) :

$$
\begin{gathered}
\mathrm{r}_{2,1}=\frac{0,75}{\operatorname{Max}(1 ; 0,75 ; 0,25)}=\frac{0,75}{1}=0,75 \\
\mathrm{r}_{2,2}=\frac{1}{\operatorname{Max}(1 ; 1 ; 0,75)}=\frac{1}{1}=1
\end{gathered}
$$




$$
\begin{gathered}
\mathrm{r}_{2,3}=\frac{0,75}{\operatorname{Max}(1 ; 0,75 ; 0,25)}=\frac{0,75}{1}=0,75 \\
\mathrm{r}_{2,4}=\frac{1}{\operatorname{Max}(1 ; 1 ; 0,75)}=\frac{1}{1}=1
\end{gathered}
$$

Alternatif A3 (1 kali gaji pokok) :

$$
\begin{gathered}
\mathrm{r}_{3,1}=\frac{0,5}{\operatorname{Max}(1 ; 0,75 ; 0,50)}=\frac{0,5}{1}=0,5 \\
\mathrm{r}_{3,2}=\frac{0,75}{\operatorname{Max}(1 ; 1 ; 0,75)}=\frac{0,75}{1}=0,75 \\
\mathrm{r}_{3,3}=\frac{0,25}{\operatorname{Max}(1 ; 0,75 ; 0,25)}=\frac{0,25}{1}=0,25 \\
\mathrm{r}_{3,4}=\frac{0,75}{\operatorname{Max}(1 ; 1 ; 0,75)}=\frac{0,75}{1}=0,75
\end{gathered}
$$

Dari hasil perhitungan di atas maka di dapat matriks ternormalisasi $r$ sebagai berikut di bawah ini :

$$
\mathrm{rij}=\left\{\begin{array}{cccc}
1 & 1 & 1 & 1 \\
0,75 & 1 & 0,75 & 1 \\
0,50 & 0,75 & 0,25 & 0,75
\end{array}\right\}
$$

Selanjutnya proses perangkingan diperoleh sebagai berikut di bawah ini :

Vektor bobot $=(20 \%, 20 \%, 30 \%, 30 \%)$

$$
\begin{aligned}
\mathrm{V} 1 & =((20 \%)(1)+(20 \%)(1)+(30 \%)(1)+(30 \%)(1)) \\
& =20 \%+20 \%+30 \%+30 \% \\
& =100 \%
\end{aligned}
$$

$$
\begin{aligned}
& \mathrm{V} 2=((20 \%)(0,75)+(20 \%)(1)+(30 \%)(0,25)+ \\
& \begin{aligned}
(30 \%) & (1)) \\
= & (15 \%+20 \%+22,5 \%+30 \%) \\
= & 87,5 \%
\end{aligned}
\end{aligned}
$$$$
\mathrm{V} 3=((20 \%)(0,5)+(20 \%)(0,75)+(30 \%)(0,25)+
$$$$
(30 \%)(0,75))
$$$$
=(10 \%+15 \%+7,5 \%+22,5 \%)
$$$$
=55 \%
$$

Berdasarkan perhitungan di atas V1 (bonus 2 kali gaji pokok) $=100 \%$, V2 (bonus $1 \frac{1}{1} 2$ kali gaji pokok) $=87,5 \%$, dan $\mathrm{V} 3$ (bonus 1 kali gaji pokok) $=55 \%$, bonus tahunan yang diberikan oleh PT Adiperkasa Anugrah Pratama kepada karyawan yang mempunyai bobot nilai kerja sebagai berikut :
Tabel 8 Hasil bobot nilai kerja

\begin{tabular}{|l|l|l|}
\hline No & Bonus Tahunan & Bobot nilai kerja \\
\hline 1 & 2 kali gaji pokok & $100 \%$ \\
\hline 2 & $11 / 2$ kali gaji pokok & $87,5 \%$ \\
\hline 3 & 1 kali gaji pokok & $55 \%$ \\
\hline
\end{tabular}

\section{Desain Sistem}

Tahap berikutnya adalah membuat desain sistem baru, dan sebelum aplikasi dibangun dilakukan terlebih dahulu rancangan proses dengan menggunakan diagram usecase untuk mengetahui fungsi apa saja yang ada di dalam sistem informasi dan siapa saja yang berhak menggunakan fungsifungsi tersebut [10].

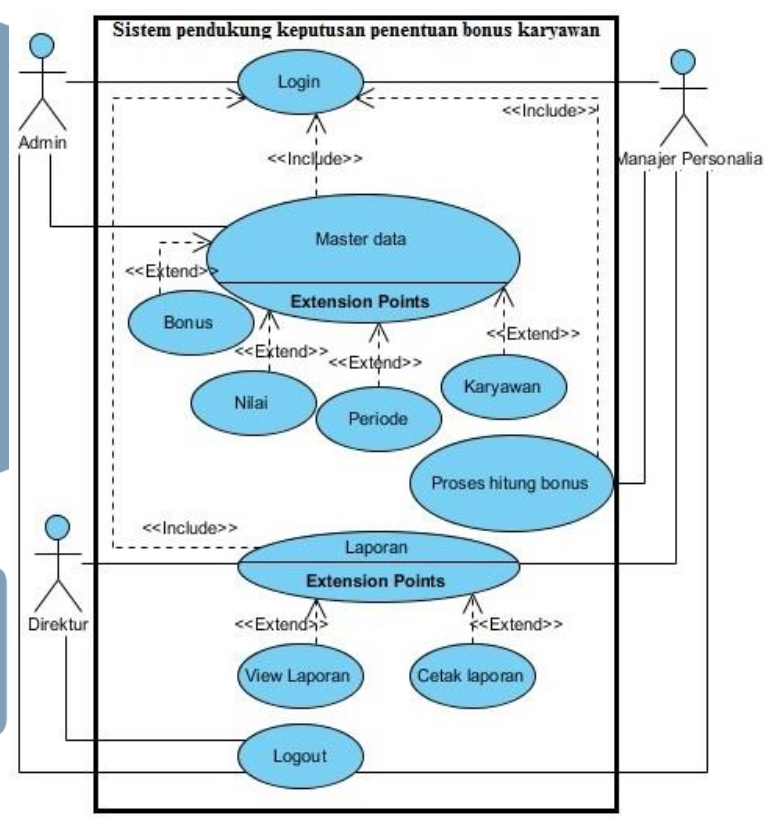

Gambar 1.Usecase diagram rancangan aplikasi sistem penunjang keputusan penentuan bonus

Dari gambar di atas dapat diketahui bahwa terdapat 3 user yang berinteraksi dengan sistem yaitu admin, manager personalia dan direktur. Berikutnya rancangan class diagram yang menggambarkan seluruh objek yang terlihat dalam sistem informasi [11] berorientasi objek sebagai acuan dalam membangun database, yang dapat dilihat pada gambar di bawah ini: 


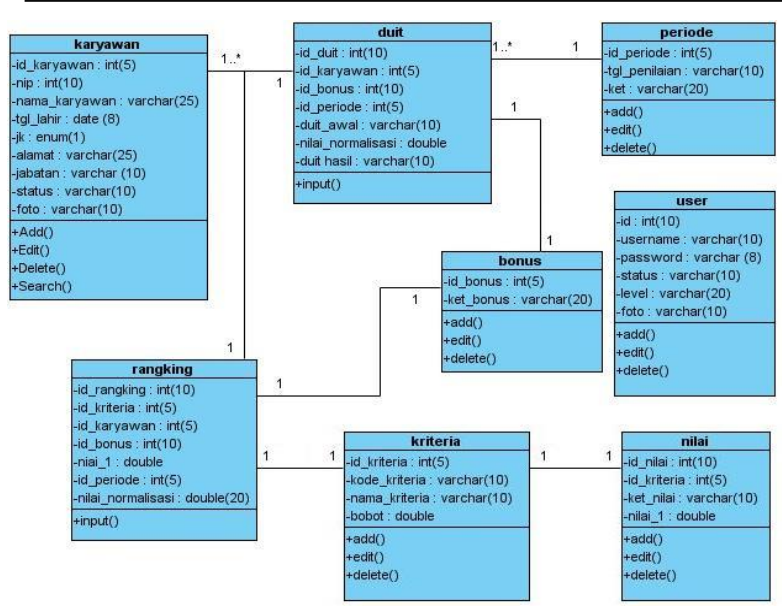

Gambar 2. Class diagram rancangan aplikasi sistem penunjang keputusan penentuan bonus

Pada gambar 2 di atas dapat dijelaskan bahwa untuk membangun database sistem penunjang keputusan penentuan bonus karyawan, dibutuhkan 8 tabel yang terdiri dari tabel karyawan, tabel rangking, tabel kriteria, tabel nilai, tabel bonus, tabel duit, tabel user, dan tabel periode.

\section{Implementasi}

Berikut adalah hasil rancangan aplikasi sistem penunjang keputusan penentuan bonus karyawan menggunakan bahasa pemrograman PHP dengan sublime text 3

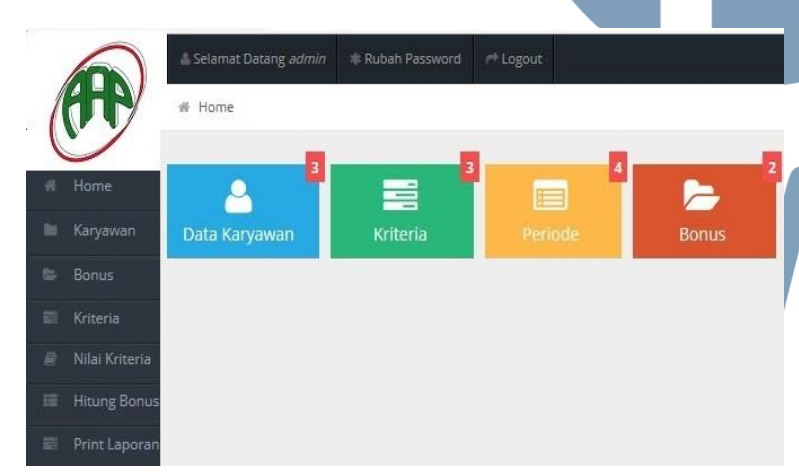

Gambar 3 Halaman utama aplikasi

Gambar 3 di atas merupakan tampilan utama dari aplikasi setelah user berhasil memasukkan sandi dengan benar pada halaman login, di halaman utama ini terdapat menu data karyawan, kriteria, periode, bonus, nilai kriteria, hitung bonus, dan print laporan bonus karyawan.

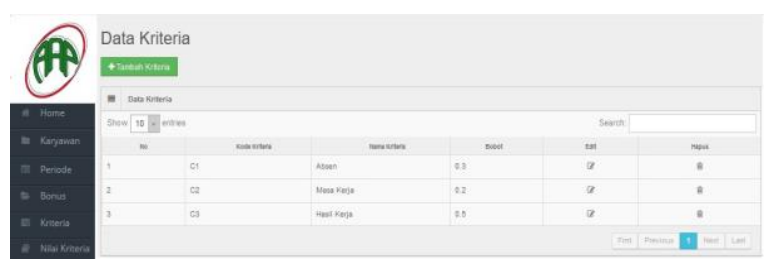

Gambar 4. Tampilan Kriteria
Gambar 4 di atas merupakan tampilan data kriteria yang akan diinput dengan kriteria masa kerja, jabatan, fungsi departemen dan hasil kinerja dengan bobotnya masing-masing.

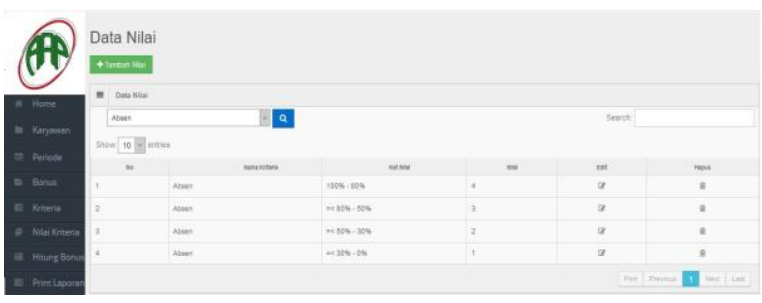

Gambar 5.Tampilan nilai kriteria

Pada gambar 5 menunjukkan tampilan input nilai kriteria dalam bentuk persentase.

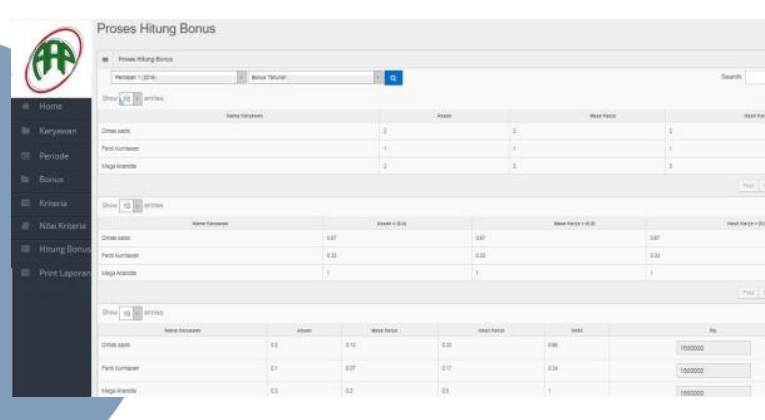

Gambar 6. Tampilan proses hitung bonus

Gambar 6 di atas adalah tampilan proses hitung bonus karyawan dengan menginput kriteria masa kerja, jabatan, fungsi departemen dan hasil kinerja, maka sistem akan melakukan proses kalkulasi dan hasil dari perhitungan penentuan besaran bonus karyawan dapat dilihat pada gambar 7 di bawah ini :

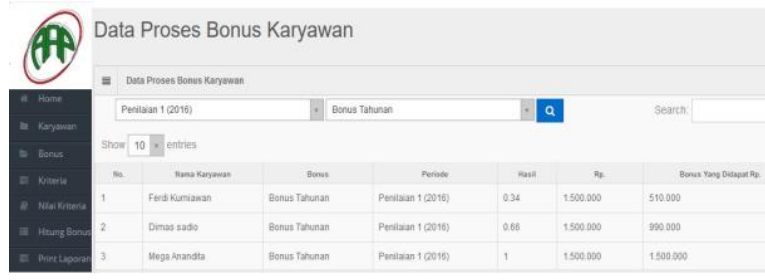

Gambar 7. Tampilan hasil perhitungan penentuan bonus karyawan

\section{E. Evaluasi}

Setelah mencoba sistem aplikasi penunjang keputusan penentuan bonus karyawan, user (Manajer Personalia) mengisi formulir penilaian yang telah disediakan penulis, dan hasilnya terangkum dalam tabel 9 di bawah ini. 


\section{ISSN 2085-4579}

Tabel 9. Hasil penilaian user berdasarkan PIECES framework

\begin{tabular}{|c|c|c|}
\hline & Parameter & Hasil Penilaian User \\
\hline \multirow[b]{2}{*}{$\begin{array}{c}0 \\
0 \\
\vdots \\
\vdots \\
\vdots \\
\vdots \\
0 \\
0 \\
0\end{array}$} & Throughout & $\begin{array}{l}\text { Aplikasi berjalan baik tanpa } \\
\text { hambatan (errors) }\end{array}$ \\
\hline & $\begin{array}{l}\text { Respond } \\
\text { time }\end{array}$ & $\begin{array}{l}\text { Hanya membutuhkan waktu } \\
\text { kurang dari } 5 \text { menit untuk } \\
\text { proses input, kurang dari } 2 \text { detik } \\
\text { untuk proses pembatalan dan } \\
\text { proses pencarian data. }\end{array}$ \\
\hline \multirow{3}{*}{$\begin{array}{c}\frac{5}{5} \\
\frac{1}{0} \\
0 \\
0 \\
0 \\
0 \\
0\end{array}$} & Accurate & $\begin{array}{l}\text { Hasil perhitungan bonus telah } \\
\text { sesuai dan tidak ada kesalahan }\end{array}$ \\
\hline & Relevant & $\begin{array}{lrr}\text { Informasi } & \text { yang } & \text { dihasilkan } \\
\text { aplikasi } & \text { sesuai } & \text { kebutuhan } \\
\text { Manajer Personalia } & \\
\end{array}$ \\
\hline & On time & $\begin{array}{l}\text { Laporan yang } \begin{array}{c}\text { dihasilkan } \\
\text { aplikasi bersifat automaticly } \\
\text { sehingga tepat waktu }\end{array} \\
\end{array}$ \\
\hline 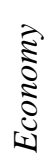 & Cost & $\begin{array}{l}\text { Aplikasi ini mengurangi } \\
\text { penggunaan kertas (paperless) }\end{array}$ \\
\hline 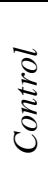 & $\begin{array}{l}\text { System } \\
\text { control }\end{array}$ & $\begin{array}{l}\text { Kontrol sistem sangat baik } \\
\text { dengan menggunakan log in } \\
\text { untuk keamanan sistem dan } \\
\text { dilengkapi pesan kesalahan. }\end{array}$ \\
\hline \multirow{2}{*}{ 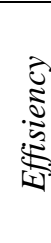 } & $\begin{array}{l}\text { Sumber } \\
\text { daya biaya }\end{array}$ & $\begin{array}{l}\text { Adanya aplikasi sudah tidak } \\
\text { memerlukan material kertas dan } \\
\text { pengurangan tinta printer. }\end{array}$ \\
\hline & $\begin{array}{l}\text { Sumber } \\
\text { daya tenaga }\end{array}$ & $\begin{array}{l}\text { Proses yang singkat cukup } \\
\text { hanya dilakukan oleh Manajer } \\
\text { Personalia saja. }\end{array}$ \\
\hline 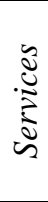 & $\begin{array}{l}\text { Proses } \\
\text { layanan }\end{array}$ & $\begin{array}{l}\text { Proses layanan aplikasi sangat } \\
\text { baik dengan memberikan } \\
\text { kecepatan respon, kemudahan } \\
\text { proses input dan informasi yang } \\
\text { dihasilkan dengan akurat. }\end{array}$ \\
\hline
\end{tabular}

PHP dengan sublime text 3 dan database MySQL dapat meningkatkan kinerja Manajer Personalia dalam proses perhitungan bonus tahunan karyawan dengan hasil perhitungan yang akurat dan dapat dipertanggungjawabkan dengan baik.

\section{DAFTAR PUSTAKA}

1] S.J.Kuryanti dan N.Indriyani, "Penentuan Bonus Karyawan Dengan Menggunakan Metode Analytic Network Process (Studi Kasus : PT. Asahimas Flat Glass, TBK Jakarta)", Prociding Seminar nasional dan teknologi Universitas Muhammadiyah Jakarta, 2016, hal 1-9.

2] M.A.Dewi, Suliyanih dan J.Marlieana, "Dashboard Sistem Informasi Keuangan dalam Mendukung Proses Pengambilan Keputusan,“Journal Semnasteknomedia, 2013, hal. 17-185.

3] P.C. Fishburn, A Problem-Based Selection of Multi-Atribute Decision Making Method. Blackwell Publishing. 1967

4] R. Savitri, "Sistem Pendukung Keputusan Penentuan Bonus Dengan Menggunakan Metode Simple Additive Weighting (Studi Kasus : PTPN III Sei Karang)", Jurnal Pelita Informatika Budi Darma, Vol. VIII. No. 3, 2014, hal 167-171.

5] Zulkifli dan Sariffudin, "Decision Support System Pemberian Bonus Tahunan Pada Karyawan Berdasarkan Kinerja Karyawan Menggunakan Metode Simple Additive Weighting (Studi Kasus : STMIK Pringsewu)", Jurnal TAM, Vol. 7, 2016, hal. 67-73.

6] E. Turban dan J.E.Aronson, Decision Support Systems and Intelligent Systems. 6th edition. Prentice Hall: Upper Saddle River, NJ. 2001

7] Kusumadewi, Fuzzy Multi-Attribut Decision Making (Fuzzy MADM), Graha Ilmu, Yogyakarta, 2006

8] A. Nugroho, Rekayasa Perangkat Lunak Menggunakan UML dan Java, Andi Offset: Yogyakarta, 2010, hal. 6.

9] R. Taufiq, Sistem Informasi Manajemen, Konsep Dasar, Analisa Dan Metode Pengembangan, Graha Ilmu : Yogyakarta, 2013, hal. 154.

[10] M.A.Dewi, "Implementasi Scrum Model Development pada Monitoring Inventory Control Cleaning Equipment dan Chemical PT. Explore Global Solution", Jurnal Ultima Infosys, Vol. VIII. No.8, 2017, hal 112-117

1] M.A.Dewi, "Digital Racking Number Guna Memaksimalkan Just In Time-Distribusi Di Warehouse Finished Good PT. Softex Indonesia", Proceedings Konferensi Nasional Sistem dan Informatika (KNS\&I), 2015, hal. 260-265

Dari tabel 9 di atas menunjukkan bahwa aplikasi telah berjalan dengan baik dan dapat menghasilkan informasi sesuai dengan tujuan yang diinginkan user dalam menunjang keputusan penentuan bonus karyawan.

\section{SIMPULAN}

Adapun kesimpulan dari penelitian ini adalah sebagai berikut :

1. Penggunaan metode simple additive weighting berhasil dilakukan untuk menentukan besaran bonus tahunan karyawan menggunakan kriteria masa kerja, jabatan, fungsi departemen dan kinerja karyawan dengan hasil perhitungan yang sangat obyektif.

2. Hasil rancangan aplikasi sistem penunjang keputusan penentuan bonus karyawan yang dibangun menggunakan bahasa pemrograman 